\title{
Influences of Sustainability Labels on Fashion Buying Behaviour - A Study on the Example of Fair Trade in Germany
}

\author{
Jochen Strähle $^{1}$, Hannah Wirtz ${ }^{1}$ \& Deniz Köksal ${ }^{1}$ \\ ${ }^{1}$ School of Textiles and Design, Reutlingen University, Reutlingen, Germany \\ Correspondence: Jochen Strähle, Professor, School of Textiles and Design, Reutlingen University, Reutlingen, 72760, \\ Germany. Tel: 49-7121-271-8073.
}

Received: May 4, 2016

doi:10.5430/ijba.v7n4p11
Accepted: May 25, 2016

Online Published: June 28, 2016

URL: http://dx.doi.org/10.5430/ijba.v7n4p11

\begin{abstract}
Purpose - The purpose of this paper is to find out the influences of sustainability labels on fashion buying behaviour. Despite key information about Fair Trade is provided in all stores of the sample company, customers seem not to be aware of the Fair Trade concept. Therefore this paper aims to give recommendations for a fashion retailer in terms of elucidation about Fair Trade by answering the following research questions: Which influences do sustainability labels wield on customer's buying behaviour? Are consumers of textile products aware of the function and backgrounds of the Fair Trade label?

Design/methodology/approach - A paper-based questionnaire was administered to 128 customers of a German fashion retailer "Adler Modemärkte AG" in four city stores from which 127 were correctly completed. Additionally an adjusted self-completion questionnaire administered to 50.000 customers online from which a total of 1.712 were correctly completed. Descriptive analysis and cross-tabulations were applied to abstract the main research findings and evaluate the hypotheses.
\end{abstract}

Findings - Key findings suggest that Adler should either enhance their communication strategy regarding Fair Trade or remove Fair Trade products from the assortment, as the majority of respondents are not aware of Adlers' Fair Trade products. The Fair Trade label could neither be identified as consumer-barrier nor sales support. Further findings revealed participants have more knowledge about Fair Trade than initially assumed.

Research limitations/implications - Majorly women aged between 56 and 75 participated in the survey. Findings are limited to geography, the target group of the fashion retailer Adler, gender, age group and the research method questionnaire.

Keywords: fair trade, sustainability labels, attitude-behaviour gap, social desirability bias, buying behaviour

\section{Introduction}

Germany is historically one of the biggest markets for organic products (predominantly food) in Europe (Wright and McCrea, 2008). A steady growth in this segment can be recorded for the past ten years (Janssen and Hamm, 2014). The majority of participants in a representative poll in Germany in 2006 showed their willingness to pay (WTP) for organic and Fair Trade (FT) products with a premium compared to conventional products (Andorfer and Liebe, 2015). Based on this study, enhanced consumer awareness for FT products can be assumed in Germany. As a consequence of the collapse of the apparel factory complex Rana Plaza 2013 in Savar, a city in Bangladesh (Saini, 2015), the German Federal Minister for Economic Cooperation and Development, Dr. Gerd Müller, initiated the so-called "Textilbündnis" in 2014 (Hackenberg, 2015). This bound of fashion brands, associations and any organisations related to social or textile aspects shall work out a distinctive action plan to strengthen sustainable supply chains. The "Textilbündnis" however is not unique insofar as currently three other countries (Note 1) are involved in so-called action-plans to improve and spread knowledge about sustainability in textiles. All three countries worked out a combined action plan together called "ECAP - European Clothing Action Plan" ("ECAP European clothing action plan," 2015). Germany does not participate in this action plan. The German government's intention is further to motivate interested citizens to deepen their knowledge about the variety of textile labels. To this regard, the Federal Ministry for Economic Cooperation and Development launched in February 2015 "Siegelklarheit" (Note 2), a website dedicated to visualize the differences of thirteen textile labels (Bender, 2015). 
The numerous textile labels used in Germany can be classified into four major groups: cotton, environment, health and social (see Table 1). Several labels cannot be put into one particular classification group as they aim to fulfil diverse certification requirements. This overview reflects the difficulty for the average textile customer to distinct between the available labels, as the majority of them fulfil two or three requirements at the same time. Table 1 doesn't include labels, which have been developed by fashion brands or retailers themselves. (Note 3)

Table 1. Source: own figure referring to BMZ (2015)

\begin{tabular}{|c|c|c|c|}
\hline Cotton & Environment & Health & Social \\
\hline \multirow{2}{*}{$\begin{array}{l}\text { BCI Better Cotton } \\
\text { Initiative }\end{array}$} & Blauer Engel & Blauer Engel & Fair Wear Foundation \\
\hline & Blue Sign & GOTS-Global Organic & GOTS-Global Organic \\
\hline \multirow{7}{*}{$\begin{array}{l}\text { Cotton Made in Africa } \\
\text { Fair Trade Cotton }\end{array}$} & EU Ecolabel - Textil & Textile Standard & Textile Standard \\
\hline & $\begin{array}{l}\text { GOTS-Global Organic Textile } \\
\text { Standard }\end{array}$ & $\begin{array}{l}\text { Textiles Vertrauen - } \\
\text { Ökotex }\end{array}$ & $\begin{array}{l}\text { BCI Better Cotton } \\
\text { Initiative }\end{array}$ \\
\hline & Naturtextil IVN zertifiziert & & Cotton Made in Africa \\
\hline & BEST & & Fair Trade Cotton \\
\hline & GRS Global Recycled Standard & & Fair Trade \\
\hline & Ökotex - made in green & & BSCI \\
\hline & Fair Trade Cotton & & \\
\hline
\end{tabular}

The following part of introduction focuses predominantly on the sustainable textile label Fair Trade. The FT-movement evolved from a niche phenomenon as an ethical aim of consumer groups to a serious mainstream economical business, addressing different customer groups influenced by the change of attitudes towards organic and FT products (Note 4) (Wright and McCrea, 2008). According to Rice, (2006), it can be considered as both, "an activist and a consumerist movement". The necessity of fair compensation and the creation of a prospering economical environment in developing countries is and has been the goal for FT for more than 50 years by now (Renard, 2003). The FT organization aims at setting fair and long-lasting business partnerships between producers and traders, predominantly in developing countries. The producer can negotiate the prices for products directly and skip intermediary. To achieve economical sustainability in this system, farmers and producers shall pay their workers a minimum wage according to the ILO-standards. (Note 5) As part of the FT-concept, farmers should use sustainable, environmental-friendly practices to grow their crop. As a characteristic for FT, supported production, small farmers organize themselves democratically in groups to reach a bigger market influence (Mohan, 2009). FT offers a variety of products covering groceries (e.g. coffee, chocolate or rice), cotton-textiles, spices, flowers, gold and soccer balls (Fair Trade, 2014). Due to the current interest in fair products and sustainable produced goods, retailers are facing a growing demand for FT products (Huet, 2013). In 2014, consumers in Germany bought FT-labelled products worth 827 million EUR, which makes up a total growth of $26 \%$ compared to the former year. The growing influence of FT products is reflected in textiles, which realise a growth of $120 \%$ from 2013 to 2014, along with honey and mixed soft drinks (Fair Trade, 2014). Eight million purchased textile FT pieces resulted in a FT bonus of about 500.000 EUR to the farmers Fair Trade (2014) \& Fair Trade (2015). The FT organization plans to introduce its own certification of the whole textile supply chain. The launch of this FT textile standard will approximately be in the first quarter of 2016 (Fair Trade, 2015). FT products don't necessarily have to be organic and organic products don't aim to classified as FT (Ruigrok, 2011). However, the percentage of organic related textile FT products rose from 9\% in 2013 up to $26 \%$ in 2014 (Fair Trade, 2014).

The German fashion retailer Adler Modemärkte AG was chosen for this study because the company, one of the first German fashion retailers, started to sell FT products in 2010 (Textilwirtschaft, 2010). The paramount goal of the survey is to carve out the influences of the FT label on Adler customers and to understand customer's knowledge about FT and if this knowledge can be assessed as a major criterion for the example of an ethical consumer. Therefore the following research questions have been developed: Which influences do sustainability labels wield on customer's buying behaviour? Are consumers of textile products aware of the function and backgrounds of the Fair Trade label? Additional to these aims the survey is designed to gather information about general ethical buying behaviour. Subsequently related questions are: Where do customers buy groceries and do they care about the origin of everyday goods? Do they donate money to charity organizations on top of buying FT products? The research 
about the Adler customer is conducted both in-store and online. This article is structured as follows: The theoretical basis of what has been examined in research before is being reviewed in part 2. Following to this the disposed research techniques for this paper are being presented in part 3 . The results of this methodology are presented and discussed in part 4. A general conclusion of the results as well as a recommendation of action for Adler is presented in chapter 5 . This article is being closed with Chapter 6 by illustrating the research limitations and implementations of this study.

\section{Literature Review and Hypotheses Development}

Numerous studies in psychology, ecology and economy deal with the role of FT. Superior research issues are customer role, customer perspective and WTP so far (De Pelsmacker et al., 2005; Grankvist and Biel, 2007). Customer's interest in organic and FT products increased significantly within the past ten years. Correspondently scientific interest focused on the average FT customer. However, in Germany only a modicum of research dealt with the FT customer in particular. Due to this fact, purchasing behaviour is dependent on cultural backgrounds, to define a profile for an ideally FT customer is not likely to happen. Because cultural backgrounds in Western Europe don't differ drastically, research about FT customers in neighbouring European markets are helpful to understand the particular German FT customer.

Ethical consumption can be defined as "the conscious and deliberate decision to make certain consumption choices due to personal moral beliefs and values" (Oh and Yoon, 2014). The market size for ethical consumption has tripled during the last decade, though the financial crisis in 2008 decreased customer's willingness to buy price-sensitive products (Jägel et al., 2012). Hence the question how to define today's ethical consumer has become a subject of interest. Several factors influence the ethical consumer: economic constraints, social status and class, attitude as well as personal ethic values in FT-consumption (Andorfer, 2013). Considering ethical consumption in terms of economic constraint, predominantly consumers with higher income are more likely to pay a premium for products labelled as "ethical" (Note 6) and approve in general a higher WTP for ethical goods, compared with low income consumers (Liebe and Preisendörfer, 2007). However, not only monetary capital but also cultural capital can have a huge impact on the ethical consumption behaviour. The social status may lead to an ecosystem of people who expect their participants to have a certain amount of knowledge about ethical products. (Andorfer, 2013) In addition to social status and class, the social demeanour of consumers are to be considered prior, when describing an ethical consumer (De Pelsmacker and Janssens, 2007). The more a consumer does appreciate a product, the more likely the buying decision will turn out to be positive. Ajzen ("Theory of planned behaviour", 1991) detailed the correlation between the consumer's acceptance of a product and a positive buying decision. According to this model, "the behavior of interest is influenced by the individual's readiness to perform this behavior (i.e., intentions to buy FT products), which in turn is influenced by the individual's positive or negative evaluation of a particular behavior (i.e., attitudes towards buying FT products), a subjective norm (i.e., an individual's perception about buying FT products influenced by the judgment of significant others such as parents, colleagues and close friends), and perceived behavioural control (i.e., perceived difficulty or ease in buying FT products)" (Ladhari and Tchetgna, 2015). Several determinants about FT-buying behaviour have been added in other studies (Ladhari and Tchetgna, 2015): Consumer knowledge (De Pelsmacker and Janssens, 2007), Quantity and quality about FT (De Pelsmacker and Janssens, 2007), Ethical obligations and self-identity (Shaw and Shiu, 2003), Moral motives (Varul, 2009), Socially responsible attitudes (Long and Murray, 2013), and FT corporate evaluation (Kim et al., 2010).

A positive attitude towards ethical organisations and their work as a general concern about the environment, influences the purchase decision (Andorfer, 2013). Public criticism in terms of unfavourable or wrong information and negative experience due to a lack of transparency by a company producing ethical products will decrease consumer's trust in a product offer. Subsequently a lower expectation level causes negative assessment by customer's towards ethical products (De Pelsmacker and Janssens, 2007). Though the effect of religiousness seem not strongly influence ethical buying behaviour, individual ethical values do have an impact (Doran and Natale, 2011). Ethical consumers individual values should also be considered as pointing "to general guidelines for individual action and shed light on pertinent moral motives and beliefs underlying ethical consumption practices beyond consumers' economic constraints" (Andorfer, 2013). Oh and Yoon (2014) argue, "consumers are transforming themselves from rational consumers valuing quality and price into ethical consumers whose priorities for product choice centre around ethical values." Ethical consumers look for opportunities to support initiatives and companies, which do not harm the environment and any creature with their buying behaviour. Consequently they "demand consumption ethics in daily life" (Oh and Yoon, 2014). Consumer decisions in favour of ethical products have purchasing power to influence social behaviour and to challenge unethical production such as sweatshop labour. 
Consumers who support ethically produced goods distinguish themselves from those who do not care and thereby "construct their own consumer identity as moral persons" (Varul, 2009).

Between the customer's will to support initiatives to abolish poverty in developing countries and their decisions to buy ethical a cap is to be noticed. Reasons, to name only two, may be social pressure on the one hand, and idealistic plans on the other hand. Sales figures prove the market share of FT products to be quite small, whereas consumer's self-awareness reveals the importance of FT products for their self-esteem (Andorfer, 2013). Nicholls and Lee (2006) described this phenomenon as "ethical purchase gap". They refer to studies recognizing "significant differences between consumers' intentions to consume ethically, and their actual purchase behaviour" (Bray et al., 2011). The "ethical purchase gap", based on the attitude-behaviour gap, is characterized as a phenomenon in which consumers show highly positive emotions and thoughts towards a specific product but don't actually buy it (Carrington et al., 2010). Numerous labels and certificates don't support necessarily a correct and fair amount of information about the ethical buying experience they promote. Subsequently, several labels are facing questions about their trustworthiness. Additionally, consumer's awareness about ethical buying is confused by the plenitude of eco and bio labels (Brécard, 2014). Though FT does not claim to be on top of ecology related labels, consumers associate FT along with eco and bio-labels (Harbaugh et al., 2011). As a consequence, even ethical conscious consumers may mix up the meanings behind the labels. Ruigrok (2011) concluded, mass consumers lacking the necessary knowledge of the average consumer to distinct FT and organic labels. As described above, FT does not intent to label organic products, because organic products cannot all be characterized as fairly produced. Organic farming happens in developed as well as developing countries. A variety of different competing certification institutes entering the markets, increase consumer's confusion. Each label follows its own certification guidelines. Contents and approaches among labels may overlap. However, consumers have to stay informed constantly to understand the distinctions between different labels. To facilitate the use of labels for consumer's benefit, Brécard (2014) claims, eco-labels should harmonize their standards, to diminish consumer confusion. The vast amount of eco-labels minimizes consumer's interest and lessens the value of ethical labels. Andorfer and Liebe (2015) argue, customer's lack information about production prices and production backgrounds of goods lead to a loss of trust towards manufacturer and product. The seller (e.g. supermarket) should provide the right amount of information to get the customer's interest, though avoiding alienating him with an information overload. Overloading information will decrease consumer's interest in the product. The credibility of a label or certificate is essentially linked to consumer's comprehension (De Pelsmacker et al., 2006). Media reports about failed FT-certification processes undermine the perception of FT-goods. Consumers are easily influenced by negative information published and may stick to their state of knowledge (Ruigrok, 2011). The average consumer's trust in FT and comparable labels can be described as fragile. Repeatedly or randomly perceived negative information could lead to the loss of interest in buying ethically labelled products (Mahé, 2010).

A "green-label" may have a huge impact on the sales figures as studies show (e.g. eco-friendly tuna) (Teisl et al., 2002). Eco labels ignited change of production mechanism in the apparel industry after factories began to offer organic fibres. Manufactures achieved premiums for sustainable produced goods (Nimon and Beghin, 1999). QR codes and green smartphone apps could enhance the perception of green labels for the product itself (Atkinson, 2013). Eco-labels may trigger a so-called "halo-effect" on products (Sörqvist et al., 2015). The "halo-effect" "consists of the circumstance, that several products with the FT logo are used to create the impression, that the whole product range of the manufacturer or retailer, including also large corporations, is linked with the concept and its values" (Stefańska and Nestorowicz, 2015). The "halo-effect" may increase positive perception of the product and cause positive emotions on the part of the consumer "even there is no reasonable relation between the product label and what is being evaluated about the product" (Sörqvist et al., 2015). This may also affect the buying behaviour of customers as a consequence.

Although customer's knowledge about textiles and food products are not necessarily comparable to each other, the research results about FT food consumers can partly be conferred to FT cotton consumers. With one pivotal limitation: textiles can never be distinguished from food products with the characteristic taste. Evaluating the literature on FT so far, the research interest on FT and its influences focuses predominantly on food products. This phenomenon is explicable because the history of FT began in the 1950's for FT products whereas the first licences for FT cotton were granted in 2005 worldwide, in Germany 2007 (Fair Trade, 2015). The FT label is unique insofar as dealing with both, textile and food products, whereas all other labels are focussed on one or the other (see label-overview in chapter 1).

The buying behaviour with regard to FT products is undoubtedly complex. Today's FT consumers cannot as easily be assessed as decades ago, when FT evolved from a niche phenomenon to mainstream label (Ingenbleek and Reinders, 2013). Pivotal questions come up: Do FT products support a company's efforts to build and influence 
brand loyalty? Are there comprehensible reasons for a consumer to pay a premium for FT products? The majority research on FT consuming focuses on the WTP and behavioural intentions (De Pelsmacker et al., 2006; Koppel and Schulze, 2013; Loureiro and Lotade, 2005; Rousseau, 2015). However, the motives which cause a consumer's decision to pay a premium can be enlightened with psychological research (Kim et al., 2010).

Fair Trade Buying Behaviour (FTBB) is strongly linked to individual ethical consumption values. Nevertheless, several studies indicate, that global values appear to be outstanding motifs in influencing ethical decision-making (Fraj and Martinez, 2006; Grankvist et al., 2007; Shaw et al., 2005). Kim et al., (2010) concluded ethical consumption values to be a superior motif "in forming consumers' evaluations of and directing subsequent behaviours for Fair Trade Brands" compared with global values. Ethical consumption as value is perceived as the main driver for the purchase of FT products, when FT values match with individual ethical values. Subsequently, FT products are assumed to fulfil the consumer's own aspirations to comply with ethical consumption (Kim et al., 2010).

Product and corporate associations should be involved as well (Brown and Dacin, 1997). Consumer decisions refer likely to former experiences with a FT product or a FT promoting company. If a T-Shirt didn't match the quality and design expectations, the consumer will probably neither recommend this product nor intend a repurchase. A consumer, interested in repetitive purchases, will probably long for additional background information about the producing company. A consumer, satisfied with the product as such, but getting information the producer is not keeping up with moral standards, will presumably not buy products of this company in the future. As FT products in general demand a premium compared with conventional products, consumers may lose the interest in keeping up their buying behaviour for a specific product or company. Though a comprehensive outcome, the influence on FTBB cannot be generalized, as consumer's individual ethical approach may differ (Kim et al., 2010). FT is used for marketing concepts to appeal consumers' interest for the product, the points of sale (e.g. supermarket) and to support a positive perception about the FT. Based on this marketing strategy, producer and seller are able to justify premiums compared to conventional products and channel public's awareness about FT (Koppel and Schulze, 2013).

What are the main motifs for customers to become a FT-consumer? If customers do link FT and certified products to the attributes "right" and "correct" (Andorfer and Liebe, 2012), the probability to accept product and label is rising. Second, if a customer has no concerns or scepticism towards FT as label distributing organisation, trusts in the underlying concept, he is most likely purchasing FT products (De Pelsmacker and Janssens, 2007). Additionally, a consumer can misuse his buying behaviour to let the morals of FT reflect on him as well. As a matter of fact, a FT-consumer isn't necessarily an overall organic-product consumer but may have an elevated awareness about the environment and fairly traded products compared with consumers of conventional products. (Andorfer and Liebe, 2012) Brécard (2014) argue, if a green-labelled product will be sold at the same price like an unlabelled product, more people would buy the labelled product as "good quality", because these characteristics are associated with the labelled product.

By considering existing literature the following Hypotheses are developed in order to answer the research questions of the study at hand:

H I: Consumers have no well-grounded knowledge about Fair Trade.

H II: Active FT-consumers are convinced; their buying behaviour can change the circumstances in developing countries.

H III: Green consumers also buy FT products.

H VI: Assimilated prices of labelled and un-labelled products increase awareness of labelled products.

H V: Additional product information (e.g. labels and stand-up displays close to the product) do not enhance consumer's awareness of FT.

H VI: The FT-label influences the purchase decision.

\section{Research Design and Methodology}

This study is based on a survey accomplished in November and December 2015. Because of the quantified results, this study will be classified as a quantitative research. The results will be collected with the statistic programme SPSS and the data calculation programme Excel. The analysis of the results will be done with the descriptive statistics and cross-tabulations to identify the main research findings as well as evaluating the hypotheses, which have been developed in chapter two. The validity of the questionnaires used has been checked during prea-tests. 


\subsection{Sample}

Adler is a fashion retailer with a focus on a consumer target group of 45 years age and upward. The company is an employer of more than 4,000 employees with 178 stores in four countries. The product assortment can be described as middle-priced with a high standard of quality. In 2014, Adler sales revenue totalled 535 Mio. EUR. Adler is one of the first German retailers, offering FT products with the beginning of 2010 (Adler, 2015). Therefore the assumption is justified; Adler customers should have a minimum of knowledge about FT and its concepts. According to internal data FT products make a total of less than one per cent of the assortment. The study "Top Shops 2015" of Textilwirtschaft (Textilwirtschaft, 2015), the leading trade magazine, revealed that one per cent of the participants $(\mathrm{N}=3.013)$ of the survey classified Adler as a retailer who is highly engaged in topics like sustainability, eco-friendliness, energy-friendliness and the absence of harmful substances.

This study is based on a sample of customers from the German fashion retailer Adler Modemärkte AG. The methodological medium survey was identified as the most appropriate and accessible technique to collect information about the insight and background knowledge on FT, based on a comparable large number of customers. To address as many customers as possible, the questionnaire was proposed to customers in four stores directly and to customers who signed up for the Adler-newsletter via Email (50.000 people in total). One of the most cited researchers in comparable market studies, Patrick de Pelsmaker, also used the medium survey as scientific method to study consumer attitude and behaviour. He put the so-called "attitude-behaviour gap" in the centre of his research about FT (De Pelsmacker et al., 2005). This phenomenon describes the gap between the consumer's willingness to buy ethical products but the not-resulting consumption choices for these products (Antonetti and Maklan, 2015). A reason for the attitude-behaviour gap may be the "social desirability bias" (Cowe and Williams, 2000). Social desirability bias accrues if respondents "do not provide fully accurate responses to questions, especially in reference to topics of a sensitive nature. This most likely occurs when the characteristic, behaviour, or attitude being measured conflicts with existing social norms and is perceived as being undesirable or even unacceptable by most of society" (Gittelman et al., 2015). Bray et al. (2011) claim, social-desirability bias can be described as "over reporting of ethical actions by research respondents seeking to give the "right" answer". In order to reduce the social desirability bias, specific questions have been arranged or removed from the in-store-questionnaire for the Email-questionnaire (e.g. the question about their WTP for FT products, see the following paragraph). As equivalent, the in-store survey was constructed as a dialogue and not self-completed as the respondents are mainly of high age and had difficulties to read the questions.

\subsection{Questionnaire Development and Design}

The structure and content of the questionnaire are based on the hypotheses, developed in chapter two. A questionnaire was used to determine the influence and nature of values effecting consumer decision making in this context (Shaw et al., 2005). The items addresses in the questionnaire are based on evaluation of different studies. An important basis for the questionnaire design was the study "Top Shops 2015" made by Textilwirtschaft in 2015 (Textilwirtschaft, 2015) as a pivotal orientation to shape particular questions. A second inspiration for the questionnaire derived from a research on FT and its influences in buying behaviour from Patrick de Pelsmaker (De Pelsmacker et al., 2006). In a first part of the questionnaire, the respondents were asked to name labels, which they pay attention to when they go shopping. (Note 7) A variety of labels was presented to them including textile and food labels (e.g. Bio-Label), all aiming to certify ecology, sustainability or FT. The interviewees were asked if, how often and what kind of FT products they purchase. For the questionnaire, FT products were selected predominantly of the food-sector, but customers could choose FT-textile-products as well. Consecutively customers were asked to name the characteristics, they associate with FT products and furthermore if they know Adler FT labelled products. The following question addressed the knowledge of customers about criteria, which products have to meet to be labelled with the FT seal. Additionally customers were asked about the points of sale where they buy their groceries (e.g. supermarket, discounter or local market). These questions are designed to confirm or falsify hypotheses one (I) three (III) and five (V). In a second part of the questionnaire, respondents were asked to give additional information to gather insights in their buying behaviour. Customers were asked if they could influence or change the living conditions in developing countries with their buying behaviour. A pivotal question of the survey, based on the study "Top Shops 2015" of Textilwirtschaft (Textilwirtschaft, 2015), addressed the question how customers assess their WTP for FT products. The question addresses an assumed social-desirability bias. Respondents could assert to be willing to pay a premium for a FT product because of detailed information about the aims of FT. In the stationary survey respondents were asked to particularize an exact estimation in EUR. The online survey focused instead of attributes, which FT products should have, to pay a premium, based on a Likert-type rating scale. The followed questions dealt with the individual donation behaviour. Respondents were asked to specify the amount of money they 
donate every year to charitable organisations and if they prefer to donate money to FT directly (only in the stationary survey) instead of buying FT products and if they know about former or current FT-projects. These questions are designed to confirm or falsify hypotheses two (II), four (IV) and six (VI). The final part of the questionnaire addresses statistical information about gender, age and profession.

\subsubsection{Stationary Survey: Content and Implementation}

The paper-based in-store survey was accomplished in four German cities: Bad Kreuznach, Wiesbaden, Saarbrücken, Worms. These four stores are clustered as "city-stores" according to Adler. A city store is defined as a store, which is located in city-centres and not in a shopping centre. With the exception of Worms, the other three cities are dominated "FT cities" (Fair Trade Deutschland, 2015a). According to FT Deutschland, FT cities prescribe to support FT and its products in the commune (Fair Trade Deutschland, 2015b). The survey took place in the four cities on 12.11.2015 and 13.11.2015. Store managers and some of the sales personnel were informed beforehand. Customers were not informed in advance, to avoid pre-information about FT. The participants received chocolate as give away. All in all, 128 people participated in the in-store survey. One person aborted the survey, which results in 127 validatable interviews.

\subsubsection{Online Survey: Content and Implementation}

The online survey was sent to all clients who receive the Adler newsletter. The questions differed slightly from those of the in-store survey. The online-survey started two weeks after the in-store survey. It was compiled with the online-tool www.webropolsurveys.com. The participants received $20 \%$ discount on their next online purchase as give away. The questionnaire was sent to 50.000 people, included in the Newsletter, and 1.712 took part in the survey (respond rate of $3.4 \%$ ).

\subsection{Hypotheses Indicators}

In order to confirm or falsify the hypotheses developed in chapter two, the answers given to specific questions will show the relationship between the questions asked in the survey and the hypotheses. Consequently, the answers of the respondents directly support or abnegate the corresponding hypothesis (Table 2).

Table 2. Indicators for hypotheses (own figure)

\begin{tabular}{|c|c|}
\hline Hypothesis & Indicators \\
\hline I. Consumers have no well-grounded & 1. Frequency of label-recognition \\
\hline \multirow[t]{2}{*}{ knowledge about Fair Trade. } & 2. Knowledge about FT-certification criteria \\
\hline & 3. Knowledge about FT-projects \\
\hline \multirow{3}{*}{$\begin{array}{l}\text { II. Active FT-consumers are convinced; their } \\
\text { buying behaviour can change the } \\
\text { circumstances in developing countries. }\end{array}$} & 1. Affirmation of buying FT products \\
\hline & $\begin{array}{l}\text { 2. Affirmation conviction to change circumstances with buying } \\
\text { behaviour }\end{array}$ \\
\hline & 3.Affirmation of buying FT products to help other people \\
\hline \multirow[t]{2}{*}{ III. Green consumers also buy FT products. } & $\begin{array}{l}\text { 1. Location for grocery shopping: wholefood shop, } \\
\text { bio-supermarket, market }\end{array}$ \\
\hline & 2. Affirmation of buying FT products \\
\hline
\end{tabular}

IV. Assimilated prices of labelled and 1. Affirmation: respondent will acknowledge price increase of FT un-labelled increase awareness of labelled products

$\begin{array}{ll}\text { products. } & \text { 2. Affirmation: Knows and buys at least two labels }\end{array}$

V. Additional product information (e.g. labels 1. Knowledge if ADLER offers FT products

and stand-up displays close to the product) do 2. Knowledge of FT-assortment at ADLER

not enhance consumer's awareness of FT. 3. Frequency of buying clothes

VI. The FT-label influences the purchase 1. Affirmation of buying FT products. decision.

2. Affirmation: growing interest in FT and similar organizations since starting buying FT products

3. Affirmation: respondent feels good when buying FT products

4. Affirmation: personal environment emphasizes FT 


\section{Findings and Discussion}

The data collected in the stationary and the online survey have been registered in Excel first and then imported to SPSS for further analysis. The data have been checked in consideration of validity, completeness, missing data and irregularities. As the quantity of online-respondents is more than ten times above the stationary survey, the focus of the findings will be on the online survey. However, the findings of the two parallel researches will be related later on.

To start with demographic criteria, age and gender have been selected to define the online-respondent (Note 8). According to Table 3 above the majority (58.5\%) of the respondents are between 56 and 75 years old and correspond perfectly to the target group of Adler. Notable $72.4 \%$ of the respondents are female customers.

Table 3. Overview age and gender of respondents online-survey (own figure based on research results)

\begin{tabular}{|c|c|c|c|}
\hline \multirow{2}{*}{\multicolumn{2}{|c|}{ Demographic criterion }} & \multirow{2}{*}{$\begin{array}{l}\text { Absolute frequency } \\
\text { (online sample) }\end{array}$} & \multirow{2}{*}{$\begin{array}{l}\text { Relative frequency } \\
\text { (online-sample) }\end{array}$} \\
\hline & & & \\
\hline \multirow[t]{4}{*}{ Gender } & Male & 431 & 25,2 \\
\hline & Female & 1.240 & 72,4 \\
\hline & No response & 3 & 0,2 \\
\hline & Abstention & 38 & 2,2 \\
\hline \multirow[t]{7}{*}{ Age } & $>35$ years & 51 & 3 \\
\hline & $36-55$ & 568 & 33,2 \\
\hline & $56-75$ & 1.001 & 58,5 \\
\hline & $<75$ & 66 & 3,9 \\
\hline & No response & 4 & 0,2 \\
\hline & Abstention & 22 & 1,3 \\
\hline & $\mathrm{N}$ & 1.712 & 100 \\
\hline
\end{tabular}

\section{Findings H I: Consumers have no well-grounded knowledge about Fair Trade}

The first indicator for H I Frequency of label-recognition (Table 4; multiple answers possible) reveals the three most recognised labels are Bio-Siegel (93.7\%), Textiles Vertrauen (90.6\%) and Fair Trade (74.8\%). As multiple criteria could be chosen, the sum of respondents is higher than 1.712 . Only about $30 \%$ of the respondents recognised the other two labels GEPA and GOTS. FT claims, 8 out of 10 customers know the FT label (Fair Trade, 2015), which can be verified insofar almost $75 \%$ of the polled customers affirmed to know the FT label. All figures considered every respondent identified 3.24 labels.

Table 4. Frequency label recognition online-survey (own figure based on research results)

\begin{tabular}{llll}
\hline \multicolumn{4}{l}{ Overview answers question Do you know the following labels? } \\
\hline Labels & $\mathrm{N}$ & Per cent & Percent of cases \\
\hline Knows Bio Label & 1.604 & 29,1 & 93,7 \\
\hline Knows GEPA Label & 571 & 10,4 & 33,4 \\
\hline Knows GOTS Label & 510 & 9,2 & 29,8 \\
\hline Knows Textiles Vertrauen Label & 1.551 & 28,1 & 90,6 \\
\hline Knows Fair Trade Label & 1.280 & 23,2 & 74,8 \\
\hline Total & 5.516 & 100,0 & 324,1 \\
\hline
\end{tabular}

Table 4 is to be read as follows: $\mathrm{N}=$ number of times the respondents identified a label; Per cent $=$ percentage given is related to $\mathrm{N}$ of the label and total $\mathrm{N}=5.516$; Per cent of cases = percentage given is related to $\mathrm{N}=1.702(1.702$ valid answers from total 1.712) 
The results for the second indicator Knowledge about FT-certification-criteria can be seen on Table 5. The appropriate answers about the certification criteria are: Farmers receive a bonus, Farmers receive fair wages, No forced labour, Freedom of association and No child labour. Table 5 displays the replies for the question about the knowledge on FT certification criteria. As multiple criteria could be chosen, the sum of respondents is higher than 1.712. The three most selected answers turned out to be (see Table 5): "Farmers receive fair wages" (69.7\%), "No forced labour" (65.9\%) and "No child labour" (75.2\%). Just 20.5\% of the respondents didn't show any knowledge about the FT certification criteria at all. Because the respondents had chosen mostly three out of five possible correct answers, this indicator doesn't support H I. The respondents identified 3.19 criteria at an average.

Table 5. Frequencies multiple responses: FT-certification criteria (own figure based on research results)

\begin{tabular}{|c|c|c|c|c|c|c|}
\hline \multicolumn{7}{|c|}{ Case Summary } \\
\hline & \multicolumn{6}{|l|}{ Cases } \\
\hline & Valid & & Missing & & Total & \\
\hline & $\mathrm{N}$ & Per cent & $\mathrm{N}$ & Per cent & $\mathrm{N}$ & Per cent \\
\hline \$FT a) & 1280 & $74,80 \%$ & 432 & $25,20 \%$ & 1712 & $100,00 \%$ \\
\hline
\end{tabular}

a) Dichotomy group tabulated at value 1 .

\begin{tabular}{|c|c|c|c|c|}
\hline \multicolumn{5}{|c|}{ \$FT certification criteria Frequencies } \\
\hline & & \multicolumn{2}{|c|}{ Responses } & \multirow[t]{2}{*}{ Per cent of Cases } \\
\hline & & $\mathrm{N}$ & Per cent & \\
\hline \multirow[t]{8}{*}{ \$FTCC a) } & FT certification criteria Renunciation of fertilizer & 276 & $6,70 \%$ & $21,60 \%$ \\
\hline & FT certification criteria Farmers receive a bonus & 523 & $12,80 \%$ & $40,90 \%$ \\
\hline & FT certification criteria Farmers receive fair wages & 892 & $21,80 \%$ & $69,70 \%$ \\
\hline & FT certification criteria No forced labour & 844 & $20,60 \%$ & $65,90 \%$ \\
\hline & FT certification criteria Freedom of association & 225 & $5,50 \%$ & $17,60 \%$ \\
\hline & FT certification criteria No child labour & 963 & $23,50 \%$ & $75,20 \%$ \\
\hline & FT certification criteria Manual crop & 109 & $2,70 \%$ & $8,50 \%$ \\
\hline & FT certification criteria No knowledge & 262 & $6,40 \%$ & $20,50 \%$ \\
\hline Total & & 4.094 & $100,00 \%$ & $319,80 \%$ \\
\hline
\end{tabular}

a) Dichotomy group tabulated at value 1 .

Cases in this context mean respondent. Table 5 is to be read as follows: $\mathrm{N}=$ number of times the respondents identified this criterion as a valid one; Per cent $=$ percentage given is related to $\mathrm{N}$ of the criterion and total $\mathrm{N}=4.094$; Per cent of cases = percentage given is related to $\mathrm{N}=1.280$ (as 1.280 marked criteria with "yes")

Considering the last indicator Knowledge about FT projects, the results suggest the respondents don't have any knowledge about FT-projects. Only one person was able to name two FT-projects ("COMSA Honduras for fair coffee" and "Canaan Fair Trade Trees for life"). Many respondents didn't understand the question correctly and replied with "chocolate" or "I don't like Fair Trade".

Taking the results of all indicators together it can be summarised, the first hypothesis is falsified as two out of three indicators result in positive FT knowledge.

Findings H II: Active FT-consumers are convinced; their buying behaviour can change the circumstances in developing countries

To verify this hypothesis, the variable "Affirmation of buying FT products" is chosen as the dependent variable. All in all, 624 people affirmed, they buy FT products, which make $36.4 \%$ of the total sample. $6.25 \%$ of these FT-consumers indicate, they buy FT products very often (daily to weekly), $41.9 \%$ frequently (weekly to monthly) and 51.2\% irregular to seldom (Note 9) These numbers imply, affirmed FT-consumers can be classified as active 
FT-consumers as only four of all customers, who ever bought a FT-product have stopped purchasing products with the FT label.

Table 6 shows a cross-tabulation of the two parameters "Buys FT products" and "Change of circumstances with buying behaviour". Although predominantly active FT consumers among the respondents consider to be able to influence circumstances such as living conditions in developing countries (answers 1-3) should be taken into account while evaluating H II, a view on non-active FT consumers should give interesting insights. A view at the tabulation reveals active FT consumers are more sceptical about the effects of their buying behaviour. Non-active FT consumers are comparably more convinced their product choice will make a difference to circumstances in developing countries. 59.46\% active FT consumers consider their buying behaviour won't make a significant difference in developing countries but that every kind of support may lead to positive developments. $4.7 \%$ of the active FT-consumers consider they cannot change anything with their buying behaviour. This provokes the question why do they buy FT products then, if they don't think it will lead to any changes? To find an answer to this contradiction, a second cross-tabulation using a different parameter will be examined in the subsequent Table 7 .

Table 6. Cross-tabulation Buys FT products * Change of circumstances (own figure based on research results)

\begin{tabular}{|c|c|c|c|c|c|c|}
\hline \multicolumn{7}{|c|}{ Buys FT products * Change of circumstances with buying behaviour Cross-tabulation } \\
\hline & & \multicolumn{4}{|c|}{ Change of circumstances with buying behaviour } & \multirow[t]{2}{*}{ Total } \\
\hline & & $\begin{array}{l}\text { Yes, } \\
\text { totally. }\end{array}$ & $\begin{array}{l}\text { Maybe not a } \\
\text { lot, but every } \\
\text { kind of support } \\
\text { may do good. }\end{array}$ & $\begin{array}{l}\text { Only if we } \\
\text { all pull the } \\
\text { string } \\
\text { together. }\end{array}$ & $\begin{array}{l}\text { No, I cannot } \\
\text { change anything } \\
\text { with my buying } \\
\text { behaviour. }\end{array}$ & \\
\hline \multirow{4}{*}{$\begin{array}{l}\text { Buys FT No } \\
\text { products }\end{array}$} & Count & 106 & 519 & 321 & 142 & 1088 \\
\hline & $\begin{array}{l}\% \text { within Change of } \\
\text { circumstances with BB }\end{array}$ & $56,10 \%$ & $58,30 \%$ & $69,50 \%$ & $83,00 \%$ & $63,60 \%$ \\
\hline & Count & 83 & 371 & 141 & 29 & 624 \\
\hline & $\begin{array}{l}\% \text { within Change of } \\
\text { circumstances with BB }\end{array}$ & $43,90 \%$ & $41,70 \%$ & $30,50 \%$ & $17,00 \%$ & $36,40 \%$ \\
\hline \multirow[t]{2}{*}{ Total } & Count & 189 & 890 & 462 & 171 & 1712 \\
\hline & $\begin{array}{l}\% \text { within Change of } \\
\text { circumstances with BB }\end{array}$ & $100 \%$ & $100 \%$ & $100 \%$ & $100 \%$ & $100 \%$ \\
\hline
\end{tabular}

$\mathrm{N}=1.712$

Consumers have a positive perception about the impact of their buying behaviour. The result of the first three answers combined, indicate a total number of $95.4 \%(\mathrm{~N}=595)$ of active FT-customers, who believe in the impact of their buying behaviour. Table 7 reflects customers' responses about buying FT products in general, as well as their self-perception about their buying behaviour of FT products in order to support other people (e.g. the producers). Active FT-customers buy FT products at least to support other people "a little bit" $(32.7 \%)$ and mostly to act supportive (46.7\%). According to this tabulation 39.8\% of non-active consumers didn't answer question, whereas all of the active FT-consumers gave at least one reply. Referring to the question above an isolated question about the impact of one's buying behaviour doesn't reveal an indication consumer's motifs to buy FT products. Motifs can be beyond the willingness to change circumstances in developing countries. In this case it is the "simple" support of other people, not specifically from developing countries. 
Table 7. Cross-tabulation Buys FT products * Customer's self-perception: supportive (own figure based on research results)

\begin{tabular}{|c|c|c|c|c|c|c|c|}
\hline \multicolumn{8}{|c|}{ Buys FT products * Customer's self perception: supportive Cross-tabulation } \\
\hline & & \multicolumn{5}{|c|}{ Customer's self perception: supportive } & \multirow[t]{2}{*}{ Total } \\
\hline & & $\begin{array}{l}\text { No response } \\
\text { given. }\end{array}$ & No, not at all & A little bit. & $\begin{array}{l}\text { Yes, } \\
\text { totally. }\end{array}$ & Abstention & \\
\hline \multirow{4}{*}{$\begin{array}{l}\text { Buys FT No } \\
\text { products }\end{array}$} & Count & 432 & 83 & 206 & 211 & 156 & 1.088 \\
\hline & $\begin{array}{l}\text { \% within } \\
\text { Customer's self } \\
\text { perception: } \\
\text { supportive }\end{array}$ & $100,00 \%$ & $55,70 \%$ & $50,20 \%$ & $42,00 \%$ & $71,20 \%$ & $63,60 \%$ \\
\hline & Count & 0 & 66 & 204 & 291 & 63 & 624 \\
\hline & $\begin{array}{l}\% \text { within } \\
\text { Customer's self } \\
\text { perception: } \\
\text { supportive }\end{array}$ & $0,00 \%$ & $44,30 \%$ & $49,80 \%$ & $58,00 \%$ & $28,80 \%$ & $36,40 \%$ \\
\hline \multirow[t]{2}{*}{ Total } & Count & 432 & 149 & 410 & 502 & 219 & 1.712 \\
\hline & $\begin{array}{l}\text { \% within } \\
\text { Customer's self } \\
\text { perception: } \\
\text { supportive }\end{array}$ & $100 \%$ & $100 \%$ & $100 \%$ & $100 \%$ & $100 \%$ & $100 \%$ \\
\hline
\end{tabular}

The analysis of the two indicators for H II concludes this hypothesis to be confirmed, as both indicators lead to a positive self-perception of the active FT-consumer.

\section{Findings H III: Green consumers also buy FT products}

Table 8 shows the frequencies of responses for the question of where the respondents buy their groceries. As displayed on Table 8, an average of 2.5 locations have been selected for grocery shopping. The three most mentioned destinations are supermarket $(88.9 \%)$, discounter $(73.2 \%)$ and local market $(50.4 \%)$. To evaluate the third hypothesis, the location for grocery shopping and the affirmation of buying FT products will be related to each other. Hereby green consumers are defined as consumers, buying their groceries at either bio-supermarkets, wholefood shops or at local markets. It is not feasible to distinguish conventional consumers from green consumers with regard to the destination supermarket or discounter, as in general many biological and FT products are available for both groups.

Table 8. Frequencies multiple response: Locations for grocery shopping (own figure based on research results)

\begin{tabular}{|c|c|c|c|c|c|c|c|}
\hline \multicolumn{8}{|c|}{ Case Summary } \\
\hline & \multicolumn{7}{|c|}{ Cases } \\
\hline & & Valid & \multicolumn{2}{|l|}{ Missing } & \multicolumn{3}{|l|}{ Total } \\
\hline & $\mathrm{N}$ & Per cent & $\mathrm{N}$ & Per cent & $\mathrm{N}$ & \multicolumn{2}{|l|}{ Per cent } \\
\hline \multicolumn{2}{|l|}{ \$Groceries a) } & $99,60 \%$ & 6 & $0,40 \%$ & 1712 & \multicolumn{2}{|l|}{$100,00 \%$} \\
\hline \multicolumn{8}{|c|}{ a) Dichotomy group tabulated at value 1 . } \\
\hline \multicolumn{8}{|c|}{ \$Groceries Frequencies } \\
\hline & & & & & \multicolumn{2}{|c|}{ Responses } & $\begin{array}{l}\text { Per cent of } \\
\text { Cases }\end{array}$ \\
\hline & & & & & $\mathrm{N}$ & Per cent & \\
\hline \multirow[t]{6}{*}{$\$$ Groceries a) } & Supermarket & & & & 1.516 & $35,50 \%$ & $88,90 \%$ \\
\hline & Discounter & & & & 1.248 & $29,20 \%$ & $73,20 \%$ \\
\hline & Bio-superma & & & & 318 & $7,50 \%$ & $18,60 \%$ \\
\hline & Wholefood-s & & & & 268 & $6,30 \%$ & $15,70 \%$ \\
\hline & Local market & & & & 860 & $20,10 \%$ & $50,40 \%$ \\
\hline & Online & & & & 58 & $1,40 \%$ & $3,40 \%$ \\
\hline Total & & & & & 4.268 & $100,00 \%$ & $250,20 \%$ \\
\hline
\end{tabular}

a) Dichotomy group tabulated at value 1 . 
Table 8 is to be read as follows: $N=$ number of times the respondents identified this answer option with "yes", Per cent $=$ percentage given is related to $\mathrm{N}$ of the grocery shopping location and total $\mathrm{N}=4.268$, Per cent of cases = percentage given is related to $\mathrm{N}=1.706$ (as 1.706 marked location with "yes")

Table 9 shows a majority of the active FT-consumers buys their groceries at local markets. The answers to the multiple choice question indicate, for those respondents who marked "market" with yes, this destination is not the main location for their grocery shopping. However, about $58 \%$ of the active FT-consumers buy groceries at local markets, indicating they care about local and high quality products. The other two location options, bio-supermarkets and wholefood shops, are less frequented than local markets. This may be due to the fact, bio-supermarkets are not available in every city yet and wholefood shops cannot offer a big assortment like supermarkets. Nevertheless $25 \%$ of the active FT-consumers declared to buy their groceries at bio-supermarkets and wholefood-shops. These results confirm H III.

Table 9. Cross-tabulation Location of grocery shopping * Buys FT products yes (own figure based on research results)

\begin{tabular}{lll}
\hline Location of grocery shopping * Buys FT products YES cross-tabulation \\
\hline & $\begin{array}{l}\text { Buys FT products YES } \\
\text { (from total N=1.712) }\end{array}$ & $\begin{array}{l}\text { \% within Buys FT products yes } \\
\text { (from total N=624) }\end{array}$ \\
\hline Bio-supermarket & 178 & 28,50 \\
\hline Wholefood-shop & 162 & 25,90 \\
\hline Local market & 360 & 57,69 \\
\hline
\end{tabular}

Findings H IV: Assimilated prices of labelled and un-labelled products increase awareness of labelled products

Adler is the first German retailer, who started to sell products made of FT-cotton in 2010. However, in 2011 the management board decided to assimilate price and design of the products due to unsatisfying the sales figures (Note 10). It could therefore be presumed, that Adler-customers showed a higher awareness of the FT-assortment afterwards. Given the data of this study, this hypothesis can neither be confirmed nor falsified. Yet according to Adler the sales didn't increase after the assimilation. However, the sales volume with FT products is not a satisfying result for the company (Note 11). The elaborated variables for this hypothesis will not contribute to come to an unambiguous result, because data from 2010 until 2015 are missing, as this is the first time a study like this is being accomplished. Taking this research approach into account it should be examined more detailed in additional research.

Findings H V: Additional product information (e.g. labels and stand-up displays close to the product) do not enhance consumer's awareness of FT

Adler stores offering FT products, supply a variety of information about FT. For example special displays on top of product carriers inform with a picture about FT cotton crop in Africa and advise three main details concerning FT (e.g. that farmers receive fair wages). In addition to that there are special hangtags on the products informing about the origin of the cotton and show the FT label. Some stores put posters, which inform about FT, close to the product. The customers can additionally inform themselves on the website of Adler about the FT product range and collect background information about FT. To verify the hypothesis first respondents have to be scrutinised, who are aware of Adler offers FT products (Table 10). Only 37.1\% of all respondents know, that Adler supplies FT products in the assortment. More than half of the sample (62.9\%) didn't know this at all. To evaluate this hypothesis the focus will be on informed respondents (those, who know the FT label). In a first step, the number of informed respondents with knowledge about Adler offering FT products will be audited. 
Table 10. Cross-tabulation Knows FT-label * Does Adler offer FT products? (own figure based on research results)

\begin{tabular}{|c|c|c|c|c|c|c|}
\hline \multicolumn{7}{|c|}{ Knows FT label * Does Adler offer FT products? Cross-tabulation } \\
\hline & & & \multicolumn{3}{|c|}{ Does Adler offer FT products? } & \multirow{2}{*}{ Total } \\
\hline & & & Abstention & Yes & No & \\
\hline \multirow[t]{4}{*}{ Knows FT Label } & No & Count & 432 & 0 & 0 & 432 \\
\hline & & \% within knows FT label & $100,00 \%$ & $0,00 \%$ & $0,00 \%$ & $100,00 \%$ \\
\hline & Yes & Count & 0 & 475 & 805 & 1.280 \\
\hline & & \% within knows FT label & $0,00 \%$ & $37,10 \%$ & $62,90 \%$ & $100,00 \%$ \\
\hline \multirow{2}{*}{ Total } & & Count & 432 & 475 & 805 & 1.712 \\
\hline & & \% within knows FT label & $25,20 \%$ & $27,70 \%$ & $47,00 \%$ & $100,00 \%$ \\
\hline
\end{tabular}

To review this hypothesis data should be regularly updated (intervals of five to ten years). For further, deeper analysis, respondents' knowledge is related to their frequency of buying clothes (Table 11).

Table 11. Cross-tabulation Does Adler offer FT products * Frequency of buying clothes (own figure based on research results)

\begin{tabular}{|c|c|c|c|c|c|c|}
\hline \multicolumn{7}{|c|}{ Does ADLER offer FT products? * Frequency of buying clothes Cross-tabulation } \\
\hline & & \multicolumn{5}{|c|}{ Frequency of buying clothes (only yes-replies taken) } \\
\hline & & weekly & monthly & half-yearly & yearly & less than yearly \\
\hline \multirow{3}{*}{$\begin{array}{l}\text { Does ADLER offer } \\
\text { FT products? }\end{array}$} & Abstention & 13 & 201 & 198 & 26 & 11 \\
\hline & Yes & 17 & 238 & 208 & 20 & 6 \\
\hline & No & 28 & 376 & 343 & 58 & 22 \\
\hline Total & & 58 & 815 & 749 & 104 & 39 \\
\hline
\end{tabular}

Because several respondents were not able to arrange their frequency they marked two options (Table 12) and the absolute figures of responses reached 1.765 . According to table 12 , the majority of respondents $(\mathrm{N}=1.712)$ buy clothes monthly (46.2\%) and half-yearly (42.4\%), which means the average Adler customer buys clothes regularly. Table 11 shows, $13.5 \%$ of the monthly-buyers and $11.8 \%$ of the half-yearly-buyers know, that Adler offers FT products $(\mathrm{N}=1.765)$. The multiple response analysis shows likewise, that the majority of the respondents buy their clothes on a regular basis. Considering all results hypothesis five is appropriate insofar Adler already supplies a variety of additional product information, whereas customer-awareness is still low.

Table 12. Frequency multiple response: frequency of buying clothes (own figure based on research results)

\begin{tabular}{|c|c|c|c|c|}
\hline \multicolumn{5}{|c|}{ \$Frequency of buying clothes Frequencies } \\
\hline & & \multicolumn{2}{|c|}{ Responses } & \multirow[t]{2}{*}{ Per cent of Cases } \\
\hline & & $\mathrm{N}$ & Per Cent & \\
\hline \multirow[t]{5}{*}{ \$Frequency a) } & weekly & 58 & $3,30 \%$ & $3,40 \%$ \\
\hline & monthly & 815 & $46,20 \%$ & $48,10 \%$ \\
\hline & half-yearly & 749 & $42,40 \%$ & $44,20 \%$ \\
\hline & yearly & 104 & $5,90 \%$ & $6,10 \%$ \\
\hline & less than yearly & 39 & $2,20 \%$ & $2,30 \%$ \\
\hline Total & & 1.765 & $100,00 \%$ & $104,10 \%$ \\
\hline
\end{tabular}

a) Dichotomy group tabulated at value 1 . 


\section{Findings H VI: The FT-label influences the purchase decision}

The final hypothesis is linked to the paramount research question, which influence sustainability labels do wield on customers. The focus, while considering the indicators for the hypothesis, will be on the emotions of the respondents, whereas the respondents' awareness is precondition for the evaluation. A cross-tabulation displaying customers' knowledge of the FT-label completed with an estimation about rising consumers' interests in FT since buying FT products enables an indication about the sway of FT to increase customer retention.

Table 13. Cross-tabulation Knows FT Label * Rising interest in FT since buying products (own figure based on research results)

\begin{tabular}{|c|c|c|c|c|c|c|c|}
\hline \multicolumn{8}{|c|}{ Knows FT Label * Rising interest in FT since buying products Cross-tabulation } \\
\hline & & \multicolumn{5}{|c|}{ Rising interest in FT since buying products } & \multirow[b]{2}{*}{ Total } \\
\hline & & $\begin{array}{l}\text { No } \\
\text { answer }\end{array}$ & $\begin{array}{l}\text { Yes, very } \\
\text { much. }\end{array}$ & $\begin{array}{l}\text { A little } \\
\text { more. }\end{array}$ & $\begin{array}{l}\text { No, not at } \\
\text { all. }\end{array}$ & Abstention. & \\
\hline \multirow{4}{*}{$\begin{array}{l}\text { Knows } \\
\text { FT } \\
\text { Label }\end{array}$} & Count & 432 & 0 & 0 & 0 & 0 & 432 \\
\hline & $\begin{array}{l}\% \text { within } \\
\text { Knows FT } \\
\text { Label }\end{array}$ & $100,0 \%$ & $0,0 \%$ & $0,0 \%$ & $0,0 \%$ & $0,0 \%$ & $100,0 \%$ \\
\hline & Count & 51 & 148 & 555 & 421 & 105 & 1280 \\
\hline & $\begin{array}{l}\% \text { within } \\
\text { Knows FT } \\
\text { Label }\end{array}$ & $4,0 \%$ & $11,6 \%$ & $43,4 \%$ & $32,9 \%$ & $8,2 \%$ & $100,0 \%$ \\
\hline \multirow[t]{2}{*}{ Total } & Count & 483 & 148 & 555 & 421 & 105 & 1712 \\
\hline & $\begin{array}{l}\% \text { within } \\
\text { Knows FT } \\
\text { Label }\end{array}$ & $28,2 \%$ & $8,6 \%$ & $32,4 \%$ & $24,6 \%$ & $6,1 \%$ & $100,0 \%$ \\
\hline $\mathrm{N}=1.712$ & & & & & & & \\
\hline
\end{tabular}

Table 13 indicates $11.6 \%$ of the informed respondents (who know the FT-label) declare their interest in FT and comparable organizations increased significantly since they started buying FT products. This figure appears to be small compared to the most popular reply, the interest in FT products rose just "a little more" (43.4\%). 32.9\% of the informed respondents revealed their interest in FT products didn't change at all after they first bought them. Based on this result, the conclusion, the label itself wields influence on the consumer retention appears to be justified and the likelihood of a re-purchase can be assumed as significantly high.

The second validation according this hypothesis deals with the self-perception of the respondents. The sample had to rate six statements on a Likert-type rating scale. The first two statements ("I buy FT products to support other people" and "I symphasize with people from developing countries") have already been validated for previous hypotheses; the remaining four are significant for the validation of $\mathrm{H} \mathrm{VI}$. The purpose of the statements is to find out the feelings and opinions consumers may have towards a FT product. The descriptive statistics results are displayed in Table 14.

Table 14. Descriptive statistics self-perception of respondents (own figure based on research results)

\begin{tabular}{llllll}
\hline \multicolumn{2}{l}{ Descriptive statistics respondent's self-perception (Note 12) } & & & \\
\hline Statements & Mean & Std. Deviation & Variance & Skewness & Kurtosis \\
\hline Good feeling due to FTBB & 1,943 & 1,4085 & 1,984 & $-0,086$ & $-1,244$ \\
\hline FT products are good for health & 1,921 & 1,4393 & 2,072 & 0,018 & 1,4532 \\
\hline Trusts FT products & 1,932 & 1,3821 & 1,910 & $-0,110$ & $-1,184$ \\
\hline Environment pays attention to FT & 1,842 & 1,4532 & 2,112 & 0,185 & $-1,276$ \\
\hline$N=1.712$ & & & & &
\end{tabular}

$\mathrm{N}=1.712$

Standard error of skewness: 0,059; Standard error of kurtosis: 0,118 
Table 14 reveals the mean to be around 2, which implies the research values for all four statements are spread around the evaluation possibility "a little bit". The standard deviations of the two statements "Good feeling due to FTBB" and "FT products are good for health" are closest to the mean of the set. Higher standard deviations are assessed for the remaining two statements "Trusts FT products" and "Environment pays attention to FT". This means for H VI, "the data points are spread out over a wider range of values" (Bland and Altman, 1996). Like the standard deviation, the variance is a dispersion measurement. The lower the values of the variance, the closer they are to the mean. The given variance-values (mean squared deviation) are not far from the mean (see Table 14) (Gravetter and Wallnau, 2007). The variance-values are also close to the mean. Only the values for the two statements "FT products are good for health" and "Environment pays attention to FT" are much more far away than the values of the other two statements, but still close to the mean. The skewness of the two statements "Environment pays attention to FT" and "FT products are good for health" (see Table 14) almost looks alike. The numbers shown on Table 14 also reflects this, as the values are close. The skewness values for the other two statements are negative. As all skewness-values are between $-1 / 2$ and $+1 / 2$ it can be stated, that the skew is approximately symmetric. Positive skewness-values mean, the data are skewed right and the right tail is long relative to the left tail (Jondeau and Rockinger, 2003). The standard error of the skeweness is close to 0 and shows therefore an almost symmetric distribution (Brownmath, 2015). The kurtosis values are all lower than 3 (compared to a normal distribution, its central peak is lower and broader, and its tails are shorter and thinner) (Brownmath, 2015). The standard error of the kurtosis is higher than the one from the skewness but still close to 0 and has therefore an almost symmetric distribution as well. A closer look to Table 14 reveal the FT-label seems to generate emotions in the respondents. If a FT product evokes a "good feeling" reaction or enhances trust in the product it is obvious, the label itself does influence the respondent. Though FT is not necessarily associated with the supply of healthy products, the respondents seem to have "health" in mind considering purchasing FT related products. The statement "Environment pays attention to FT" is important concerning the social-desirability-bias and halo-effect of the product. Factors to assess the hypothesis are curiosity (rising interest), good feeling, trust, health and social environment.

H VI is assessed as confirmed, based on the data according to which all respondents stated somewhat positive feelings towards the FT label. The overview about all hypotheses reveals four out of six hypotheses to be confirmed, one falsified and one without a reliable result (Table 15).

Table 15. Overview hypotheses results (own figure based on research results)

\begin{tabular}{llcc}
\hline Hypotheses & Confirmed & Falsified \\
\hline H I & Consumers have no well-grounded knowledge about Fair Trade. & $\mathrm{X}$ \\
\hline H II & $\begin{array}{l}\text { Active } \\
\text { circumstances in developing countries. }\end{array}$ & \\
\hline H III & Green consumers also buy FT products. & $\mathrm{X}$ & \\
\hline H IV & Assimilated prices of labelled and un-labelled increase awareness of labelled products. & - & - \\
\hline H V & $\begin{array}{l}\text { Additional product information (e.g. labels and stand-up displays close to the product) } \\
\text { do not enhance consumer's awareness of FT. }\end{array}$ & $\mathrm{X}$ & \\
\hline H VI & The FT-label influences the purchase decision. & $\mathrm{X}$ & \\
\hline
\end{tabular}

\section{Online survey vs. stationary survey: Similarities and Discrepancies}

As the online sample $(\mathrm{N}=1.712)$ delivered ten times more data than the stationary sample $(\mathrm{N}=127)$ only the main differences of the two surveys will be illustrated. However, basic statistical data is still specified beforehand. The average age of the stationary respondent is likewise between 56 and 75 years old (52.8\%), female (85.8\%) and a retiree $(48.8 \%)$.

$\mathrm{H}$ I: The significant difference between the frequency results for $\mathrm{H} \mathrm{I}$ is explained by the fact $50.8 \%$ of the respondents of the stationary survey couldn't name one FT-certification criterion (online: 20.5\%). All other frequencies coincide.

H II: The percentage of active stationary FT-customers $(52.0 \%)$ is just slightly higher compared to the non-active FT-customers (48.0\%), whereas the gap is much higher at the online-respondents (active: $36.4 \%$; non-active: $63.6 \%$ ). 
This could be due to the social desirability bias as the questionnaire was asked as a dialogue in-store. The active stationary-customers are more positive about the reach and influence of their buying behaviour. Almost half of the active FT-customers (43.9\%) are convinced their buying behaviour can totally make a difference to the circumstances in developing countries and $28.8 \%$ stated, every kind of support may have a positive impact. About one third $(31.1 \%)$ of the non-active FT-customers indicate they do have an impact with their buying behaviour as well. This result is similar to the online-respondents.

H IV: The amount of stationary respondents knowing about Adler FT products turns out to be significantly lower than the amount of online-respondents (stationary: $16.5 \%$, online: $37.1 \%$ ).

Neither significant similarities nor discrepancies between online and stationary survey have been found for $\mathrm{H} \mathrm{III,} \mathrm{H}$ $\mathrm{V}$ and H VI.

\section{Conclusions and Recommendations}

Numerous influences of sustainability labels (Note 13) on consumers buying behaviour as a summarising conclusion are to be concluded as a summarising answer to the basic research question of this survey. Concerning the customers' interest in both the issue and the survey, a surprisingly large number of Adler customers, stationary and online, participated in the interviews. Either the up-to-datedness of the topic sustainability or the incentives (chocolate and a $20 \%$ voucher for their next purchase) advanced the attractiveness of this survey.

The unexpected customers' knowledge about FT certification criteria reflects the common interest in the issue. However, special product characteristics were associated with FT products, which are not promoted by the FT-organization, because the product certification cannot promise them (e.g. eudermic). Customer's overestimation of the influence and reach of FT signals consumer's confusion about the vast variety of labels on the market. The overall knowledge about Adler as reseller of FT certified products turned out to be moderate. Four out of six labels possible have been recognised by more than $50 \%$ of the respondents, which is to be evaluated as a huge score. The reach of the respondent's buying behaviour indicated a significant gap between the active and the non-active FT-consumers. Peculiarly the non-active FT-consumers express an elevated positive appraisal about their power as a consumer. Active FT consumers are not as much convinced of the FT-concept and rather focus on other organizations. The passive FT customers seem to have a better perception about themselves than their actual buying behaviour can reflect (attitude-behaviour-gap). The percentage of respondents, who are aware that Adler offers FT products, turns out to be surprisingly low. Several consecutions are to be drawn from this study. The main recommendations for Adler are presented as follows.

Considering the key findings of this study Adler in specific could consider two options:

(1) Enhanced promotion for FT products.

(2) Remove FT products out of the assortment.

\subsection{Option 1: Enhanced Promotion for FT Products}

If the management board decides to keep FT labelled products in the assortment for Adler's image as social responsible company, additional advertising and promotion activities for FT labelled products and the FT organisation as such are necessary to reach an economically reward for the costly efforts. Improving the customers' knowledge and awareness may lead to an increase in customer purchases as it is "a large factor in purchase intentions" (Kelley, 2013). However, overloading the customer with too many information may result in the opposite, reducing purchases (De Pelsmacker et al., 2006). Based on the findings of the study and the insights the author recommends a target-group related marketing campaign. Adler spreads significantly advertising with the means of newspaper supplements, which reach a large number of customers. A special series about the existing FT products will refresh the customer's knowledge (if existing) and draw the attention to the variety of products offered. Special visual merchandising campaigns could support this series. This will lead to increased sales of FT labelled products on the one hand and enrich consumer's awareness about Adler's activities for the favour of sustainability in textiles on the other hand. Special employee trainings about FT and FT assortment in the stores could further enrich the dialogue between sales forces and customers. Furthermore a special joint campaign with the FT organisation could be prolific for Adler. Adler should, however, still decide about the amount of information to provide from their side and define what should be supported by FT. Another kind of joint venture could be cooperation with stores in FT-cities and the local municipality. As the municipalities are obliged to push FT it could be possible that they can offer new ways of communication for potential and existing FT-customers. 


\subsection{Option 2: Remove FT Products Out of the Assortment}

Considering the key findings and the customer's comparable low knowledge about Adler reseller of FT products, the question about the status quo of the assortment is justified. Customers yet can choose between various labels and so can Adler as well. Adler already offers GOTS-certified products and could enhance marketing activities in favour of promoting this label. $17.8 \%$ of all respondents $(\mathrm{N}=1.839)$ recognised the GOTS-label already, which signals a modicum of awareness. Additional labels, which Adler is making use of are BCI and Ökotex - made in green. Sales figures are a pivotal indicator for the decision making about keeping or forsaking the FT label. Since prices of FT labelled products have been equalized to unlabelled products, the sales figures are less than satisfying for Adler. Consumer's increasing interest to be well informed about every step in the supply chain as a matter of trust in the label and the reseller Adler, can lead to additional critical assessment. Textile FT products currently only consist of FT-labelled cotton with the consequence, the trims as well as the garment production and logistics are not FT labelled. Although FT develops an overall label for textiles, it is disputable if the FT label is strong enough to compete with other already existing sustainable textile labels (e.g. Ökotex - made in green) and if the consumer will acknowledge and accept this enhanced label.

\subsection{Transferability for Other Fashion Retailers}

Are these two recommendations applicable to a variety of fashion retailers, who offer FT products as well? The average Adler-customer of an elevated age has a high purchasing power. It may not reflect the average of German society, but can still give an indication as Germany's society is ageing (Randler et al., 2014). Howbeit is it evident for a fashion retailer to formulate an elaborated strategy for the usage of sustainability labels and to not sink into activism.

\section{Research Limitations and Implementations}

The findings of this research are limited, adaptable to the industry; insofar as the buying behaviour of only one customer's fashion retailer have been subject of the survey. In addition, Adler is focussed on an ageing target group and therefore the younger and middle-aged consumers have mainly been left out. The majority of the respondents were female. This may be due to the fact, that women of higher age buy clothes for their husbands as well. Future research should take more male consumers into account. To achieve this goal, the location of the survey location should be more attractive for men. To reach better findings, additional research should be taken to other European countries, which are considered as FT-loyal (e.g. the Netherlands). Additional research about buying behaviour with field experiments and focus-group discussions will be helpful as well to reach better-founded findings. Cooperation with psychology-focused researchers could give additional insights into the FT-consumer and push the research into a more explanatory direction. For example will it be helpful for all FT-offering-institutions (e.g. fashion retailers or food suppliers) to find out whether a FT-consumer needs a special shopping environment and if yes how this environment should be created. Looking at the findings about H II, additional research could go deeper on the actual motives of a consumer to buy FT products. Moreover should additional research work out a clearer profile of the FT consumer. For example would it be helpful to identify the exact locations and frequency of their FTBB. As the FT consumer cannot be profiled clearly it is recommendable to repeat such research every five to ten years to constantly identify customer's needs.

\section{References}

Adler. (2015). Adler [WWW Document]. Retrieved January 5, 2016, from http://www.adlermode-unternehmen.com/investor-relations/

Ajzen, I. (1991). The theory of planned behavior, 50.

Andorfer, V. (2013). Ethical Consumption in Germany. A Cross-Sectional Analysis of Determinants of Fair Trade Consumption (2000 - 2010). Z. Für Soziol., 42, 424-443.

Andorfer, V., \& Liebe, U. (2015). Do information, price, or morals influence ethical consumption? A natural field experiment and customer survey on the purchase of Fair Trade coffee. Soc. Sci. Res., 52, 330-350. http://dx.doi.org/10.1016/j.ssresearch.2015.02.007

Andorfer, V., \& Liebe, U. (2012). Research on Fair Trade Consumption-A Review. J. Bus. Ethics, 106, 415-435. http://dx.doi.org/10.1007/s10551-011-1008-5

Antonetti, P., Maklan. (2015). How categorisation shapes the attitude-behaviour gap in responsible consumption. Int. J. Mark. Res., 57, 51-72. http://dx.doi.org/10.2501/IJMR-2015-005 
Atkinson, L. (2013). Smart shoppers? Using QR codes and "green" smartphone apps to mobilize sustainable consumption in the retail environment. Int. J. Consum. Stud., 37, 387-393. http://dx.doi.org/10.1111/ijcs.12025

Bender, H. (2015). BMZ erklärt Siegel. Lebensm. Ztg.

Bland, J.M., \& Altman, D.G. (1996). Measurement error. BMJ., 312, 1654. http://dx.doi.org/10.1136/bmj.312.7047.1654

Bray, J., Johns, N., \& Kilburn, D. (2011). An Exploratory Study into the Factors Impeding Ethical Consumption. J. Bus. Ethics, 98, 597-608. http://dx.doi.org/10.1007/s10551-010-0640-9

Brécard, D. (2014). Consumer confusion over the profusion of eco-labels: Lessons from a double differentiation model. Resour. Energy Econ., 37, 64-84. http://dx.doi.org/10.1016/j.reseneeco.2013.10.002

Brownmath. (2015). Measures of Shape: Skewness and Kurtosis [WWW Document]. Retrieved December 28, 2015, from http://brownmath.com/stat/shape.htm

Brown, T.J., \& Dacin, P.A. (1997). The Company and the Product: Corporate Associations and Consumer Product Responses. J. Mark., 61, 68-84. http://dx.doi.org/10.2307/1252190

Carrington, M.J., Neville, B.A., \& Whitwell, G.J. (2010). Why Ethical Consumers Don't Walk Their Talk: Towards a Framework fpr Understanding the Gap Between the Ethical Purchase Intentions and Actual Buying Behaviour of Ethically Minded Consumers. J. Bus. Ethics, 97, 139-158. http://dx.doi.org/10.1007/s10551-010-0501-6

Crowe, R., \& Williams, S. (2000). Who are the ethical consumers? Manchester: Cooperative Bank.

De Pelsmacker, P., Driesen, L., \& Rayp, G. (2005). Do Consumers Care about Ethics? Willingness to Pay for Fair-Trade Coffee. J. Consum. Aff., 39, 363-385. http://dx.doi.org/10.1111/j.1745-6606.2005.00019.x

De Pelsmacker, P., \& Janssens, W. (2007). A Model for Fair Trade Buying Behaviour: The Role of Perceived Quantity and Quality of Information of Product-specific Attitutes. J. Bus. Ethics, 75, 361-380. http://dx.doi.org/10.1007/s10551-006-9259-2

De Pelsmacker, P., Janssens, W., Streckx, E., \& Mielants, C. (2006). Fair-trade beliefs, attitudes and buying behaviour of Belgian consumers. Int. J. Nonprofit Volunt. Sect., 11, 125-138. http://dx.doi.org/10.1002/nvsm.47

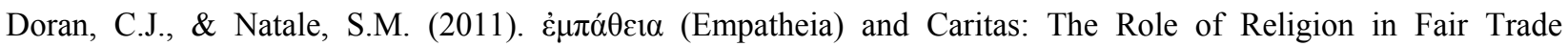
Consumption. J. Bus. Ethics, 98, 1-15. http://dx.doi.org/10.1007/s10551-010-0533-y

ECAP - European clothing action plan [WWW Document]. (2015). Retrieved January 5, 2016, from http://www.wrap.org.uk/content/ecap-european-clothing-action-plan

Fair Trade, D. (2015). 2015_Transfair Jahresbericht.

Fair Trade, D. (2014). Absatz - Fairtrade-Produkte - Fairtrade Deutschland (TransFair e. V.) [WWW Document]. Retrieved November 6, 2015, from https://www.fairtrade-deutschland.de/produkte/absatz-fairtrade-produkte/

Fair Trade Deutschland. (2015a). Fairtrade-Towns: Städteverzeichnis [WWW Document]. Retrieved November 28, 2015, from https://www.fairtrade-towns.de/fairtrade-towns/staedteverzeichnis/

Fair Trade Deutschland. (2015b). Fairtrade-Towns: Die fünf Kriterien [WWW Document]. Retrieved November 28, 2015, from https://www.fairtrade-towns.de/mitmachen/die-fuenf-kriterien/

Fraj, E., \& Martinez, E. (2006). Environmental values and lifestyles as determining factors of ecological consumer behaviour: an empirical analysis. J. Consum. Mark., 23, 133-144. http://dx.doi.org/10.1108/07363760610663295

Gittelman, S., Lange, V., Cook, W.A., Frede, S.M., Lavrakas, P.J., Pierce, C., \& Thomas, R.K. (2015). Accounting for Social-Desirability Bias In Survey Sampling - A Model for Predicting and Calibrating - The Direction and Magnitude of Social-Desirability Bias. J. Avertising Res., 6, 242-254. http://dx.doi.org/10.2501/JAR-2015-006

Grankvist, G., \& Biel, A. (2007). Predictors of purchase of eco-labelled food products: A panel study. Food Qual. Prefer., 18, 701-708. http://dx.doi.org/10.1016/j.foodqual.2006.11.002

Grankvist, G., Lekedal, H., \& Marmendal, M. (2007). Values and eco- and fair-trade labelled products. Br. Food J., 109, 169-181. http://dx.doi.org/10.1108/00070700710725527

Gravetter, F., \& Wallnau, L. (2007). Essentials of Statistics for the Behavioral Science. Cengage Learning.

Hackenberg, A. (2015). Textilbündnis nimmt Arbeit auf. Textilwirtschaft. 
Harbaugh, R., Maxwell, J.W., \& Roussillon, B. (2011). Label Confusion: The Groucho Effect of Uncertain Standards. Manag. Sci., 57, 1512-1527. http://dx.doi.org/10.1287/mnsc.1110.1412

Huet, N. (2013). Fairtrade sales to grow as consumers demand better labelling [WWW Document]. Reuters UK. Retrieved November $\quad 6, \quad 2015, \quad$ from http://uk.reuters.com/article/2013/02/28/uk-fairtrade-sales-interview-idUKBRE91R0XT20130228

Ingenbleek, P.T.M., \& Reinders, M.J. (2013). The Development of a Market for Sustainable Coffee in The Netherlands: Rethinking the Contribution of Fair Trade. J. Bus. Ethics, 113, 461-474. http://dx.doi.org/10.1007/s10551-012-1316-4

Innretail, Modint, VGT. (2013). PlanOfActionDutchTextileSector.pdf.

International Labour Organization. (2015). About the ILO [WWW Document]. Retrieved November 26, 2015, from http://www.ilo.org/global/about-the-ilo/lang--en/index.htm

Jägel, T., Keeling, K., Reppel, A., \& Gruber, T. (2012). Individual values and motivational complexities in ethical clothing consumption: A means-end approach. J. Mark. Manag., 28, 373-396. http://dx.doi.org/10.1080/0267257X.2012.659280

Janssen, M., \& Hamm, U. (2014). Governmental and private certification labels for organic food: Consumer attitudes and preferences in Germany. Food Policy, 49, 437-448. http://dx.doi.org/10.1016/j.foodpol.2014.05.011

Jondeau, E., \& Rockinger. (2003). Conditional volatility, skewness, and kurtosis: existence, persistence, and comovements. J. Econ. Dyn. Control, 27, 1699-1737. http://dx.doi.org/10.1016/S0165-1889(02)00079-9

Kelley, M. (2013). The Fair Trade Consumer: Attitutes, Behvaiours and Knowledge of Fair Trade Products (Honors Thesis). The Ohio State Universoty, Ohio.

Kim, G.-S., Lee, G.Y., \& Park, K. (2010). A Cross-National Investigation on How Ethical Consumers Build Loyalty Towards Fair Trade Brands. J. Bus. Ethics, 96, 589-611. http://dx.doi.org/10.1007/s10551-010-0486-1

Koppel, H., \& Schulze, G.G. (2013). The Importance of the Indirect Transfer Mechanism for Consumer Willingness to Pay for Fair Trade Products - Evidence from a Natural Field Experiment. J. Consum. Policy, 36, 36-387. http://dx.doi.org/10.1007/s10603-013-9234-0

Ladhari, R., \& Tchetgna, N.M. (2015). The influence of personal values on Fair Trade consumption. J. Clean. Prod., 87, 469-477. http://dx.doi.org/10.1016/j.jclepro.2014.10.068

Liebe, U., \& Preisendörfer, P. (2007). Zahlungsbereitschaft für kollektive Umweltgüter Theoretische Grundlagen und empirische Analysen am Fallbeispiel der Wertschätzung biologischer Vielfalt im Wald Willingness to Pay for Collective Environmental Goods Theoretical Foundations and Empirical Analyses Using the Example of Biodiversity in Forests. Z. Für Soziol. Heft 5, 326-345.

Long, M.A., \& Murray, D.L. (2013). Ethical Consumption, Values Convergence/Divergence and Community Development. J. Agric. Environ. Ethics, 26, 351-375. http://dx.doi.org/10.1007/s10806-012-9384-0

Loureiro, M.L., \& Lotade, J. (2005). Do fair trade eco-labels in cofee wake up the consumer conscience? Ecol. Econ., 53, 129-138. http://dx.doi.org/10.1016/j.ecolecon.2004.11.002

Mahé, T. (2010). Are Stated Preferences Confirmed by Purchasing Behaviours? The Case of Fair-Trade Bananas in Switzerland. J. Bus. Ethics, 92, 301-315. http://dx.doi.org/10.1007/s10551-010-0585-z

Mohan, S. (2009). Fair Trade and Corporate Social Responsibility. Econ. Aff., 22-28. http://dx.doi.org/10.1111/j.1468-0270.2009.01943.x

Nicholls, A., \& Lee, N. (2006). Purchase decision-making in fair trade and the ethical purchase "gap": 'is there a fair trade twix? J. Strateg. Mark., 14, 369-386. http://dx.doi.org/10.1080/09652540600956384

Nimon, W., \& Beghin, J. (1999). Are Eco-Labels Valuable? Evidence from the Apparel Industry. Am. J. Agric. Econ., 801-811. http://dx.doi.org/10.2307/1244325

Oh, J.-C., Yoon. (2014). Theory-based approach to factors affecting ethical consumption. Int. J. Consum. Stud., 38, 278-288. http://dx.doi.org/10.1111/ijcs.12092

Otto GmbH, \& Co. KG. (2007). OTTO stellt Nachhaltigkeitsbericht 2007 vor - 98 Prozent aller angebotenen Textilien "hautfreundlich - weil schadstoffgeprüft" - Otto (GmbH \& Co KG) [WWW Document]. Retrieved November

25 ,

2015 ,

from 
https://www.otto.de/unternehmen/de/newsroom/news/2007/OTTO-stellt-Nachhaltigkeitsbericht-2007-vor-98-Pr ozent.php

Oxford University Press. (2015a). organic- Definition von organic auf Englisch aus dem Oxford-Wörterbuch [WWW Document]. $\quad$ Retrieved December $\quad 4, \quad 2015, \quad$ from http://www.oxforddictionaries.com/de/definition/englisch/organic

Oxford University Press. (2015b). fair trade- Definition von fair trade auf Englisch aus dem Oxford-Wörterbuch [WWW Document]. Retrieved December 4, 2015, from http://www.oxforddictionaries.com/de/definition/englisch/fair-trade?q=fair+trade

Randler, C., Vollmer, C., Wilhelm, D., Flessner, M., \& Hummel. (2014). Attitudes Towards the Elderly Among German Adolescents. Educ. Gerontol., 40, 230-238. http://dx.doi.org/10.1080/03601277.2013.802187

Renard, M.-C. (2003). Fair trade: quality, market and conventions. J. Rural Stud., International Perspectives on Alternative Agro-Food Networks: Qua lity, Embeddedness. Bio-Politics, 19, 87-96. http://dx.doi.org/10.1016/S0743-0167(02)00051-7

Rice, G. (2006). Currents: Book review-Consuming ethically: The role of fair trade. Glob. Bus. Organ. Excell., 98-102. http://dx.doi.org/10.1002/joe.20124

Rousseau, S. (2015). The role of organic and fair trade labels when choosing chocolate. Food Qual. Prefer.,44, 92-100. http://dx.doi.org/10.1016/j.foodqual.2015.04.002

Ruigrok, W. (2011). From Niche to Mass Markets: Rival Strategies in Promoting Fair Trade Organic Commodity Chains. Anal. Krit., 01, 213-233. http://dx.doi.org/10.1515/auk-2011-0117

Saini, M. (2015). Rana Plaza Compensation Fund Falls Short. Womens Wear Dly, 209.

Schiffers, C. (2011). Ethical Production.

Shaw, D., Grehan, E., Shiu, E., Hassan, L., \& Thomson, J. (2005). An exploration of values in ethical consumer decision making. J. Consum. Behav., 4, 185-200. http://dx.doi.org/10.1002/cb.3

Shaw, D., \& Shiu, E. (2003). Ethics in consumer choice: a multivariate modelling approach. Eur. J. Mark., 37, 1485-1498. http://dx.doi.org/10.1108/03090560310487202

Sörqvist, P., Haga, A., Langeborg, L., Holmgrem, M., Wallinder, M., Nöstl, A., Saeger, P.B., \& Marsh, J.E. (2015). The green halo: Mechanisms and limits of the eco-label effect. Food Qual. Prefer., 43, 1-9. http://dx.doi.org/10.1016/j.foodqual.2015.02.001

Stefańska, M., \& Nestorowicz, R. (2015). Fair Trade In CSR Strategy of Global Retailers. Palgrave Macmillan.

Teisl, M.F., Roe, B., \& Hicks, R.L. (2002). Can Eco-Labels Tune a Market? Evidence from Dolphin-Safe Labeling. J. Environ. Econ. Manag., 43, 339-359. http://dx.doi.org/10.1006/jeem.2000.1186

Textilwirtschaft. (2015). Top Shops 2015_Stationärhandel Adler-Mode_Nachhaltigkeit.pdf.

Textilwirtschaft. (2010). Textilwirtschaft [WWW Document]. Retrieved November 25, 2015, from https://vpn.reutlingen-university.de/+CSCO+00756767633A2F2F7271662E6E2E726F667062756266672E7062 7A++/eds/pdfviewer/pdfviewer?vid=1\&sid=e9a35037-d862-4ceb-9af4-c7d41d350b5b\%40sessionmgr4001\&hi $\mathrm{d}=4110$

The Danish Fashion Institute. (2009). The NICE project | Danish Fashion Institute [WWW Document]. Retrieved January 5, 2016, from http://danishfashioninstitute.dk/en/node/757

Varul, M.Z. (2009). Ethical selving in cultural contexts: fairtrade consumption as an everyday ethical practice in the UK and Germany. Int. J. Consum. Stud., 33, 183-189. http://dx.doi.org/10.1111/j.1470-6431.2009.00762.x

Wrap UK. (2007). Sustainable Clothing Action Plan [WWW Document]. Retrieved January 5, 2016, from http://www.wrap.org.uk/content/sustainable-clothing-action-plan-1

Wright, S., \& McCrea, D. (2008). The Handbook of Organic and Fair Trade Food Marketing. Agribusiness, 24, 575-576. 


\section{Notes}

Note 1. Denmark (The Danish Fashion Institute, 2009), Netherlands (Innretail et al., 2013), United Kingdom (Wrap UK, 2007).

Note 2. Consumers can use "Siegelklarheit" to find out more about the credibility of environmental and social labels used by the textiles industry. The webpage is located on the German government's siegelklarheit.de web portal.

Note 3. Some companies promote their own certification systems like the Otto group for example. In 2007 Otto published, that $98 \%$ of the textile products were characterized with their own label ,hautfreundlich weil schadstoffgeprüft“. The certification criteria of the Otto label are based on „Textiles Vertrauen“ and can be classified as health-oriented (Otto GmbH \& Co. KG, 2007).

Note 4. Organic can be defined as ,food or farming methods: produced or involving production without the use of chemical fertilizers, pesticides, or other artificial chemicals" (Oxford University Press, 2015a) and Fair Trade can be defined as: „,between companies in developed countries and producers in developing countries in which fair prices are paid to the producers" (Oxford University Press, 2015b).

Note 5. ILO is an acronym that stands for International Labour Organization. „The main aims of the ILO are to promote rights at work, encourage decent employment opportunities, enhance social protection and strengthen dialogue on work-related issues" (International Labour Organization, 2015).

Note 6. Ethically produced goods are created in the balance between the environment (ecology), the economy and the social. Products shall be manufactured under principles relating to human rights and labour standards (Schiffers, 2011).

Note 7. The following labels were shown: Bio-Siegel, GEPA, GOTS, Textiles Vertrauen, Fair Trade.

Note 8. A detailed description of the average Adler FT customer is to be found in appendix I.

Note 9. See crosstabulation at appendix II.

Note 10. Information given by Adler on 25th of November, 2015.

Note 11. Information given by Adler on 25th of November, 2015.

Note 12. Likert-type-rating-scale: $0=$ No response given, $1=$ No, not at all., $2=\mathrm{A}$ little bit., $3=$ Yes, totally., $4=$ Abstention

Note 13. This research predominantly concentrates on FT.

Note 14. The percentages shown here are cumulated values from the online and stationary survey $(\mathrm{N}=1.839)$.

\section{Appendix}

\section{The average Adler customer in this survey (Note 14)}

The average age of the Adler customer is between 56 and 75 years old $(58.1 \%)$, female $(73.4 \%)$ and a retiree (42.8\%). The Adler customer buys his groceries at the supermarket (88.2\%), discounter (71.6\%) and local market $(48.0 \%)$.

The most known sustainable labels for him are the Bio-Siegel (92.7\%), Textiles Vertrauen $(88.7 \%)$ and Fair Trade (74.4\%) and get his attention while going shopping (Bio-Siegel: 53.5\%, Textiles Vertrauen: 62.7\%, Fair Trade: $57.9 \%)$.

The average customer did not purchase yet a FT product (62.5\%) but if he did, FT coffee (38.9\%) and FT chocolate (33.2\%) are predominantly bought. If he purchases FT products then he does it irregularly to seldom (42.4\%). If he does buy FT products, his interest into FT and comparable organizations increased slightly (31.3\%) since the first purchase.

The average Adler FT customer associates the following characteristics with FT products: eco-friendly (43.4\%) and health-friendly $(35.0 \%)$.

He doesn't know, that Adler offers FT products (49.4\%) and cannot name actual FT-projects (99.9\%).

The average Adler customer expects the FT label to fulfil the following certification criteria: payment of minimum wages (51.5\%), prohibition of forced labour (48.1\%) and abandonment of child labour (54.9\%). 
To be willing to pay a premium, the average online customer expects high quality (37.2\%), eudermic (44.4\%) and absence of hazardous substances $(50.6 \%)$. The average stationary customer is willing to pay a premium of about 1,51 $-2,00 €$ for a FT-product compared with an unlabelled product.

The motivation to buy FT products is to support other people (22.9\%). Additionally FT customers trust in the FT label (24.7\%) and consider FT products to be healthy (24.7\%).

The average Adler FT-customer buys clothes monthly (47.5\%) to half-yearly $(43.2 \%)$ and estimates the buying behaviour does not change the circumstances in developing countries substantially, but every support may lead to unspecified "something good" (50.0\%). At an average this customers declare to donate up to 50,00€ per year for charity organizations $(36.1 \%)$.

\section{Cross-tabulation Buys FT products * Frequency of buying FT products}

\begin{tabular}{|c|c|c|c|c|c|c|c|c|}
\hline \multicolumn{9}{|c|}{ Buys FT products * Frequency of buying FT products Crosstabulation } \\
\hline & & & \multicolumn{5}{|c|}{ Frequency of buying FT products } & \multirow{3}{*}{\begin{tabular}{|l} 
Total \\
\\
1088 \\
\end{tabular}} \\
\hline & & & abstention & $\begin{array}{|lr|}\text { very often } \\
\text { (daily } & \text { to } \\
\text { weekly) }\end{array}$ & \begin{tabular}{|l|} 
frequently \\
(weekly to \\
monthly)
\end{tabular} & $\begin{array}{l}\text { irregular } \\
\text { to seldom }\end{array}$ & never & \\
\hline \multirow{4}{*}{$\begin{array}{l}\text { Buys FT } \\
\text { products }\end{array}$} & \multirow{2}{*}{ No } & Count & 477 & 18 & 135 & 423 & 35 & \\
\hline & & \begin{tabular}{|lr}
$\%$ & within \\
Frequency & of \\
buying & FT \\
products & \\
\end{tabular} & $100,00 \%$ & $31,60 \%$ & $34,00 \%$ & $57,00 \%$ & $89,70 \%$ & $63,60 \%$ \\
\hline & \multirow[t]{2}{*}{ Yes } & Count & 0 & 39 & 262 & 319 & 4 & 624 \\
\hline & & \begin{tabular}{|lr}
$\%$ & within \\
Frequency & of \\
buying & FT \\
products & \\
\end{tabular} & $0,00 \%$ & $68,40 \%$ & $66,00 \%$ & $43,00 \%$ & $10,30 \%$ & $36,40 \%$ \\
\hline \multirow{2}{*}{\multicolumn{2}{|c|}{ Total }} & Count & 477 & 57 & 397 & 742 & 39 & 1712 \\
\hline & & \begin{tabular}{|lr}
$\%$ & within \\
Frequency & of \\
buying & FT \\
products &
\end{tabular} & $100,00 \%$ & $100,00 \%$ & $100,00 \%$ & $100,00 \%$ & $100,00 \%$ & $100,00 \%$ \\
\hline
\end{tabular}

